\title{
The Pattern of Iodine Food Source Intake in Early Adolescents in Junior High School in Jatinangor
}

\author{
Siti Nur Fatimah, ${ }^{1}$ Che Wan Nurdamia, ${ }^{2}$ Faisal $^{3}$ \\ ${ }^{1}$ Department of Public Health Faculty of Medicine Universitas Padjadjaran, Indonesia, ${ }^{2}$ Faculty of \\ Medicine Universitas Padjadjaran, Indonesia, ${ }^{3}$ Department of Child Health Faculty of Medicine \\ Universitas Padjadjaran/Dr. Hasan Sadikin General Hospital Bandung, Indonesia
}

\section{Abstract}

Background: Iodine is one of the essential micronutrients for normal growth, development, and metabolism throughout life. Studies about the pattern of iodine food source intake in Indonesia are lacking. The aim of this study was to assess the current pattern of iodine food source intake among early adolescents.

Methods: This was a cross-sectional study, the pattern of iodine food source intake in early adolescents aged 11-14 years attending Junior High School in Jatinangor Sumedang, Indonesia was assessed from September to October 2014, by validated food frequency questionnaire (FFQ). Eating patterns were divided into four categories based on Indonesian Recommended Dietary Allowance (RDA).

Results: The average iodine daily intake of the subjects was $356.27 \mathrm{mcg}$. The highest frequency of the iodine intake category was adequate in students aged 11-12 years old (100\%), compared to aged 13-14 years old $(79.2 \%)$.

Conclusions: The daily iodine intake in Junior High School students is sufficient. Further assessment in areas elsewhere in West Java needs to be conducted to have a better picture of the pattern of iodine food source intake in adolescents.

Keywords: Early adolescents, food source, iodine intake

\section{Introduction}

Adolescence is a particularly unique period in life because it is a transition between childhood and adulthood, characterized by a growth spurt with physiological changes until reaching approximate adult status. ${ }^{1}$ According to the World Health Organization (WHO), early adolescence has been defined as the age of 10-14 years. $^{2}$ Nutrition plays an essential role, as nutrition influences development and growth throughout infancy, childhood, and adolescence. It is, however, during the period of adolescence that nutrient needs are the greatest. $^{3}$

Iodine is one of the essential micronutrients for normal growth, development, and metabolism throughoutlife. ${ }^{4}$ The iodine has the main role in the synthesis of thyroid hormones, thyroxine (T4) and triiodothyronine (T3). ${ }^{4}$ The thyroid hormone is important to maintain the normal secretion of growth hormone by the pituitary gland, thus, when iodine food source intake is inadequate, the thyroid hormone synthesis is impaired, resulting in a series of functional and developmental abnormalities. Based on the recent estimates, the iodine intake of $29.8 \%$ or 240.9 million school-age children and early adolescents worldwide is insufficient. The highest proportions of insufficiency are found in 76 million children and early adolescents in southeast Asia, exceeding other country regions. ${ }^{5}$ Conversely, thyroid function may also be affected when there is an excess intake of iodine.

The study about the pattern of iodine food source intake among early adolescents in Indonesia is lacking, therefore, we were

Correspondence: Siti Nur Fatimah, Department of Public Health Faculty of Medicine, Universitas Padjadjaran, Jalan Eyckman No. 38 Bandung, Indonesia, E-mail: st_nurf@yahoo.com 
interested to assess the iodine food source intake among early adolescence in Jatinangor.

\section{Methods}

Descriptive research was conducted using a cross-sectional design in September-October 2014 to assess the pattern of iodine food source intake among early adolescents aged 11-14 years old who were attending a junior high school in Jatinangor, Sumedang district, Indonesia. All procedures performed in this study were approved by the Health Research Ethics Committee of Faculty of Medicine, Universitas Padjadajaran with the number of ethical clearance was No. 384/UN6.C2.1.2/ KEPK/PN/2014. Besides, the study had obtained permission from the respective Junior High School authority.

Using a cluster random sampling method, a junior high school had been selected. The data was collected using validated food intake analyzing tool in the form of a questionnaire and was self-conducted to find out how the pattern of iodine food source intake in early adolescents. The semi-quantitative Food Frequency Questionnaire (FFQ) was used to assess the frequency of which food items or food groups were consumed during a specified period time. Specific food or comprehensive item list were used to record intakes over a given period (day, week, month, year) with ranking subjects into broad categories of the low, medium, and high intakes of food components. The advantage of this method is rapid, with the low respondent burden and high response rate. Before the FFQ was distributed, students
Table 1 Characteristics of Junior High School Students $(n=80)$ in Jatinangor

\begin{tabular}{lcc}
\hline \multicolumn{1}{c}{ Characteristics } & $\mathrm{n}$ & $\%$ \\
\hline Sex & & \\
$\quad$ Male & 31 & 38.8 \\
$\quad$ Female & 49 & 61.2 \\
Age (years) & & \\
11 & 2 & 2.5 \\
12 & 30 & 37.5 \\
13 & 34 & 42.5 \\
14 & 14 & 17.5 \\
\hline
\end{tabular}

were given an adequate explanation and food models were used to help answer the FFQ.

Data obtained were converted to the size and weight based on the household size contained in the food model and food consumption survey individuals and were adjusted according to the frequency of food consumed at once. After household food in grams was obtained, then the data was totaled to calculate the iodine intake received.

After the calculation of iodine intake from FFQ the adequacy of iodine in percentage was measured based on the Indonesian Recommended Dietary Allowance (RDA) by Indonesia's Health Ministry in 2005. The percentage was obtained from the formula of $\%$ RDA, which was iodine intake $(\mu \mathrm{cg})$ from FFQ/standard iodine intake. Then, the value percentage of RDA obtained was categorized

Table 2 The Iodine Intake among Junior High School Students $(\mathrm{N}=80)$ in Jatinangor, Based on the Group of Age Category

\begin{tabular}{lcc}
\hline \multicolumn{1}{c}{ Group for age category } & N & \% \\
\hline 11-12 years old & 32 & 100 \\
Adequate & - & - \\
Mild deficiency & - & - \\
Moderate deficiency & - & - \\
Deficiency & & \\
13-14 years old & 38 & 79.2 \\
Adequate & 3 & 6.3 \\
Mild deficiency & 1 & 2.1 \\
Moderate deficiency & 6 & 12.4 \\
Deficiency &
\end{tabular}


Table 3 Frequency of Top Ten Iodine Food Source Intake among Junior High School Students in Jatinangor

\begin{tabular}{|c|c|c|c|c|c|c|}
\hline Days (n) & Weeks & Months & 2 Months & 1x/6 Months & 1x/years & Never (n) \\
\hline Rice (78) & Fried rice & Strawberry & Strawberry & Avocado & Shrimp & Seaweed (48) \\
\hline Egg (44) & $\begin{array}{l}\text { Ice cream } \\
\text { chocolate }\end{array}$ & $\begin{array}{l}\text { Ultra milk } \\
\text { chocolate, } \\
\text { vanilla, } \\
\text { strawberry, }\end{array}$ & Potato & Mussel & Mussel & Shrimp (36) \\
\hline Tea (42) & Porridge & Avocado & Salted egg & Shrimp & seaweed & Mussel (31) \\
\hline Cireng $(40)$ & Tahu Bulat & Fish ball & seaweed & Strawberry & Avocado & $\begin{array}{c}\text { Salted egg } \\
\text { (26) }\end{array}$ \\
\hline Instant coffee (37) & Instant noodle & Mango & Avocado & Seaweed & Strawberry & Potato(18) \\
\hline Balabala (35) & Balabala & Apple & Mussel & Mango & $\begin{array}{l}\text { Bakso Tahu } \\
\text { Siomay }\end{array}$ & Avocado (10) \\
\hline Fried tofu (34) & $\begin{array}{l}\text { Bakso Tahu } \\
\text { Siomay }\end{array}$ & Banana & Shrimp & Fish ball & Mango & $\begin{array}{l}\text { Frisian flag } \\
\text { condensed } \\
\text { milk (8) }\end{array}$ \\
\hline $\begin{array}{c}\text { Instant noodle } \\
\text { (29) }\end{array}$ & Tomato & Tahu Bulat & Carrot & Porridge & $\begin{array}{c}\text { Chocolate } \\
\text { bread }\end{array}$ & Tomato (7) \\
\hline $\begin{array}{l}\text { Pisang Goreng } \\
\text { Aroma(28) }\end{array}$ & Watermelon & Watermelon & Mango & $\begin{array}{c}\text { Chocolate } \\
\text { bread }\end{array}$ & Salted egg & $\begin{array}{c}\text { Pisang Goreng } \\
\text { Aroma(7) }\end{array}$ \\
\hline $\begin{array}{c}\text { Chocolate bread } \\
\qquad(26)\end{array}$ & $\begin{array}{c}\text { Chocolate } \\
\text { bread }\end{array}$ & $\begin{array}{l}\text { Ice cream } \\
\text { chocolate }\end{array}$ & Apple & Salted egg & Apple & $\begin{array}{l}\text { Chocolate } \\
\text { bread (6) }\end{array}$ \\
\hline
\end{tabular}

Note: Bakso Tahu Siomay= dumpling; Pisang Goreng Aroma= Caramelized banana

into four based on the nutritional health center personnel handbook Department of Health Republik of Indonesia (DEPKES, RI) (1990) with cut-off points: adequate $\geq 100 \%$ RDA, mild deficiency $>80-99 \%$ RDA, moderate deficiency $70-80 \%$ RDA, and deficiency $<70 \%$ RDA.

According to the Indonesian Recommended Dietary Allowance (RDA) guideline published in 2013, the recommended iodine intake for age 10-12 years old was $120 \mathrm{mcg}$ and for age 13-15 years old was $150 \mathrm{mcg}$, respectively. All data were collected and analyzed using Excel 2010 and SPSS 17.00 software for Windows.

\section{Results}

In total, 80 junior high school students were included, consisting of $31(38.8 \%)$ males and $49(61.30 \%)$ females. The characteristic of these young adolescents had been presented in Table 1 . The age of the students was in the range between 11 to 14 years old conform to the age of junior high school students.

Furthermore, the age was grouped into age 11-12 years old and 13-14 years old (Table 2 ). The average daily iodine intake among the junior high school students was 356.27
$(\mathrm{SD} \pm 222.76) \mathrm{mcg}$, with the minimum iodine intake was $66.41 \mathrm{mcg}$ and the maximum iodine intake was $976.68 \mathrm{mcg}$. The students in a group of 11-12 years old were all categorized as having adequate iodine intake; whereas only $79.2 \%$ of the students in a group of 13-14 years old were categorized as having adequate iodine intake, and thus $20.8 \%$ had an inadequate iodine intake; of whom $12.4 \%$ was deficient to iodine. Altogether, 10 of 80 (12.5\%) of this study participants had a deficiency in iodine intake. The analysis did not separate the results of iodine intake between boys and girls, because there was no difference in iodine requirements between boys and girls.

There were various iodine intakes among junior high school students, in which the frequency of the top ten in each category was presented in Table 3. The most daily consumed of iodine food sources were rice, eggs, tea, cireng, instant coffee; whereas tropical fruit and seafood-based snack were consumed less often, in the range of 40-78 respondents. The most daily consumed of vegetables and fruits that contained iodine were tomato and banana. Interestingly, some of the respondents had never eaten some food such as seaweed, shrimp, mussel, or salted eggs. 


\section{Discussion}

Based on food frequency questionnaire (FFQ) analysis, the average daily iodine food source intake among junior high school students was $356.27 \mathrm{mcg}$. This result conforms with a previous study showing a normal average of iodine food source intake in children, which was $300 \mathrm{mcg} / \mathrm{L}$, and the daily iodine is measured using urinary iodine (UI) concentration, ${ }^{6}$ suggestings that FFQ analysis might be useful to assess the iodine food source intake.

According to the Indonesian Recommended Dietary Allowance (RDA) guideline published in 2013, the recommended iodine intake is $120 \mathrm{mcg}$ for age $10-12$ years old and $150 \mathrm{mcg}$ for age 13-15 years old.7 Our study has shown that in the category of age of 11-12 years old the intake is all adequate, whereas age 13-14 years old has lower percentage for adequate iodine intake (79.2\%). Interestingly, a study in Malaysia ${ }^{8}$ using semi-quantitative FFQ has shown that the majority of the respondents have daily iodine intake above the normal requirement for a specific age. This finding might be caused by excessive iodine intake which is mainly associated with their dietary iodine food source intake. ${ }^{8}$ It is important to increase iodine food sources intake related to the role of iodine as thyroid hormone precursors. Excessive iodine intake may cause an increase in thyroid volume. Moderately high of iodine food source intake in the range of $300-500 \mathrm{mcg} / \mathrm{d}$ is well tolerated in healthy children, however, iodine intake in this range has no benefit and might cause an adverse effect. $^{6}$

The iodine food source intake that mostly consumed daily by our study participants is white rice and egg, whereas seaweed, shrimp, mussel are the lowest consumed, similar to a study in Pakistan. ${ }^{8}$ Of note, seafood such as fish, seaweed and salts are the best sources of iodine, next to milk and vegetables. ${ }^{9}$ Taken into account, a community movement has been raised by the government to eat more fish since Indonesia is a country with two-third of the region is the ocean.

Furthermore, according to RDA, iodized salt is also contributing to fulfilling the amount of iodine food source intake. Previous studies have shown that the national coverage of households with iodized salt $>5 \mathrm{ppm}$ is reported to be $78.2 \%$ in 1995 and increased to $81.5 \%$ in 1999 . Recently, salt containing iodine in Indonesia has been defined as a minimum of 30 ppm. ${ }^{10}$ Our data shows that the respondents in this study in the category age of 13-14 years old is in lower categories (20.8\%); of whom $6.3 \%$ is mild, $2.1 \%$ is moderate and $12.4 \%$ in deficiency state of iodine deficiency intake, that might possibly due to inadequate iodine food source intake; thus in total of $12.5 \%$ of our study participants (mostly in age of 13-14 years old) has iodine deficiency intake. One of the factors that may cause this problem is the differences in cost prizes between iodized salt and non-iodized salt, which in turn caused the poorer families to prefer to buy based on the price alone. Education among the mothers may also influence the use of iodine salt.10 Inadequate iodine food source intake would impair thyroid hormone synthesis, resulting in hypothyroidism.

Limitations in this study are encountered, among others is the lack of educational background and economic status of the families. This study is also limited in the method by only using the Food Frequency Questionnaire (FFQ), which might have led to recall bias. The alternative method to accurately measure the iodine intake is by using Urinary Iodine (UI) Concentration measurement.

In conclusion, the consumption of iodine food source intake in our study at junior high school students aged between 11 to 14 years old is adequate, with the average of iodine food source intake is $356.27 \mathrm{mcg}$. Special attention is required that older age students are the ones that have iodine deficiency intake. Iodine intake in daily consumption of regularly consumed food such as rice and eggs needs to be enriched with other sources, especially milk, fish and other sea origin products such as seaweed or shrimp.

\section{References}

1. Mansourian M, Marateb HR, Kelishadi $\mathrm{R}$, Motlagh ME, Aminaee T, Taslimi M, et al. First growth curves based on the World Health Organization reference in a Nationally-Representative Sample of Pediatric Population in the Middle East and North Africa (MENA): the CASPIAN-III study. BMC Pediatr. 2012;12:149.

2. World Health Organization. Nutrition in adolescence: issues and challenges for the health sector: issues in adolescent health and development. Geneva: WHO Press; 2005.

3. Mondal N, Sen J. Prevalence of stunting and thinness among rural adolescents of Darjeeling district, West Bengal, India. Italian J Pub Health. 2010;7(1):54-61.

4. Gunnarsdottir Ir, Dahl L. Iodine intake in 
human nutrition: a systematic literature review. Food Nutr Res. 2012;56:19731.

5. Andersson $M$, Karumbunathan $V$, Zimmermann MB. Global iodine status in 2011 and trends over the past decade. J Nutr. 2012;142(4):744-50.

6. Zimmerman MB, Ito Y, Hess SY, Fujieda K, Molinari L. High thyroid volume in children with excess dietary iodine intakes. Am J Clin Nutr 2005;81(4):840-4.

7. Kementerian Kesehatan Republik Indonesia. Peraturan Menteri Kesehatan Republik Indonesia No. 75 Tahun 2013 tentang Angka Kecukupan Gizi yang Dianjurkan bagi bangsa Indonesia. Jakarta:
Kemenkes RI; 2013. p. 5-10.

8. Taib SM, Isa ZM. Dietary iodine from interview-based semi-quantitative Food Frequency Questionnaire: correlation with 24h Dietary Recall. Pakistan J Nutr. 2013;12(7):688-91.

9. Imdad S, Muzaffar R, Shoukat MS. Evaluation of impact of dietary pattern on iodine and thyroid status of adolescent girls in Lahore. Biomedica. 2013;29(3):139-46.

10. Semba RD, de Pee S, Hess SY, Sun K, Sari M, Bloem MW. Child malnutrition and mortality among families not utilizing adequately iodized salt in Indonesia. Am J Clin Nutr. 2008;87(2):438-44. 